\title{
MÉXICO EN EL CONSEJO DE SEGURIDAD
}

El ocho de octubre del año 2001 la Asamblea General de la Organización de Naciones Unidas eligió a los nuevos miembros no permanentes del Consejo de Seguridad, dentro de los cuales está México. El ingreso de México al Consejo de Seguridad (CS), indudablemente es una victoria para lo que se está denominando como "la nueva diplomacia mexicana"; sobre todo ahora que México viene de un proceso político de alternancia en el poder y son altos sus "bonos" a nivel internacional como país de una democracia emergente. La membresía de México al CS tiene varias implicaciones. Una de ellas es que es una excelente oportunidad para que este país realice una política exterior activa, propositiva, imaginativa que busque, dentro de los causes del derecho internacional y en línea con la política de paz de México, medidas novedosas e inteligentes para lograr la paz y la seguridad internacionales que precisamente es el objeto fundamental del CS.

GA/9930

8 October 2001

Fifty-sixth General Assembly

Plenary

23rd Meeting (AM)

\section{TERMS TO BEGIN ON 1 JANUARY 2002}

Bulgaria, Cameroon, Guinea, Mexico and Syria were elected this morning by the General Assembly to serve as non-permanent members of the Security Council. Their two-year terms will begin on 1 January 2002, 
when they will fill the seats vacated 31 December by Bangladesh, Jamaica, Mali, Tunisia and Ukraine. Colombia, Ireland, Mauritius, Norway and Singapore will continue to serve as non-permanent Council members during 2002 for the second of their two-year terms.

In this morning's election, Bulgaria, Cameroon, Guinea and Syria received the required two-thirds majority of votes in the first round of balloting. A second round was required before Mexico was elected.

Bulgaria last served on the Council in 1985-1986, Cameroon in 19741975, Guinea in 1972-1973 and Syria in 1970-1971. Mexico last served in 1980-1981.

The Assembly's programme of work today was to elect five non-permanent members of the Council. Three were to be from Africa and Asia, one from Eastern Europe and one from Latin America and the Caribbean. In opening the balloting, President Han Seung-soo (Republic of Korea) recalled that by understanding, the three seats from among the Africa and Asia group were to be filled by two States from Africa and one from Asia.

The Assembly is expected to meet again at a time to be announced in the Journal.

\section{Elections}

The Assembly President, Han Seung-Soo (Republic of Korea) began the balloting by announcing that the five non-permanent members of the Security Council to be elected, three should be from Africa and Asia, one should be from Eastern Europe and one should be from Latin America and the Caribbean. Further, in accordance with established practice, of the three States to be elected from Africa and Asia, two should be from Africa and one from Asia.

He said three candidates had been endorsed for the three vacancies from the African and Asian States. Those were Cameroon, Guinea and Syria. There were two candidates from the Eastern European States for the one vacant seat, which were Belarus and Bulgaria. There were also two candidates for the one vacant seat from the Latin American and Caribbean States, which were the Dominican Republic and Mexico.

The election would be by secret ballot in accordance with the rules of procedure, he told the Assembly. Further, he said those candidates receiving the greatest number of votes, and a two-thirds majority, would be declared elected. The number of elected candidates would not exceed the number of vacancies to be filled. (Additional rounds of elections would be held if the two-third majority of votes were not received.) 
The following were the results of the first round of balloting to elect five non-permanent member of the Security Council for a two-year term beginning on

1 january 2002:

Number of ballot papers: 178

Number of invalid ballots: 1

Number of valid ballots: 177

Abstentions: 0

Number of Members voting: 177

Required Majority: 118

Number of Votes Obtained:

Cameroon :172

Guinea: 173

Syria: 160

Latin America and Caribbean States:

Number of ballot papers: 178

Number of invalid ballots: 1

Number of valid ballots: 177

Abstentions: 0

Number of Members voting: 177

Required Majority: 118

Number of Votes Obtained:

Dominican Republic: 60

Mexico: 116

Dominica: 1

Western Europe and Other States:

Number of ballot papers: 178

Number of invalid ballots: 3

Number of valid ballots: 175

Abstentions: 2

Number of Members voting: 173

Required Majority: 116 


\section{Number of Votes Obtained:}

Belarus: 53

Bulgaria: 120

Having obtained the two-thirds majority required, Cameroon, Guinea, Syria and Bulgaria were elected as members of the Security Council for two-year terms beginning on 1 January 2002.

A second round of voting was required to fill the one remaining Council seat. It was a vote restricted to the two States, Mexico and the Dominican Republic, that had received the most votes, but not the required two-thirds majority, for election in the first round.

Latin America and Caribbean States:

Number of ballot papers: 178

Number of invalid ballots: 0

Number of valid ballots: 178

Abstentions: 0

Number of Members voting: 178

Required Majority: 119

Number of Votes Obtained:

Dominican Republic: 40

Mexico: 138

Having obtained the required two-thirds majority, Mexico was elected a member of the Security Council for a two-year term beginning on 1 January 2002. 